\title{
Police reform in Ukraine. A reconnaissance of perceptions
}

\author{
Igor Sviatokum, Alexey Serdyuk and Petrus C. van Duyne ${ }^{1}$
}

\section{Introduction: the need for police reform in Ukraine}

After proclaiming independence in 1991, Ukraine inherited the old Soviet police system without introducing significant changes. Basically, the structure remained in place, and the first national law "On militsiya", adopted in 1990, while, technically, Ukraine was still a Soviet Republic, did not change anything in the ways the old and then new law enforcement body worked. The militsiya continued to function as a clearly militarised, heavily centralised system under the Ministry of Internal Affairs. The latter and the former were not organisationally separated, meaning that the ministry concurrently served as a central managing body of the militsiya, with the minister being de facto head of the militsiya (de jure, the relevant position did not even exist). The Soviet legacy also manifested itself in the way the performance of the militsiya was measured. Performance assessment was based primarily on the criminal statistics, measuring such indicators as number of registered crimes, clearance rate, conviction rate etc. (Markovska and Serdyuk, 2013). Indicators of the current period were compared to the relevant numbers from the previous period, making it necessary to either keep the indicators on the same level or to constantly "improve" them, but within a plausible range. This system created strong incentives for the officers to manipulate numbers in order to achieve required goals and, thus, was geared towards presenting the public with biased

1 The first two authors are, respectively, researcher at and deputy head of the Research Lab on Crime Enforcement of Kharkiv National University of Internal Affairs, Ukraine. Petrus C. van Duyne is Professor of criminal law (em) and visiting professor at Utrecht University, The Netherlands. The authors want to express their gratitude to Stefano Donati, Presidential Award Fellow at Northern Arizona University, whose grant made this research possible. 
figures from a manipulated assessment process (Markovska and Serdyuk, 2013).

The first major document expressing serious intentions of the Ukrainian government to reform the militsiya is the Resolution of the Cabinet of Ministers of Ukraine on the framework of development of the system of Ministry of Internal Affairs in 1996. The document did not address aforementioned issues, but focusing instead on the development of the militsiya within the existing framework. Later, the issue of reforming the Ministry of Internal Affairs and the militsiya had been periodically raised (in 1996-1998, in 2003, in 2005, in 2010 etc.) and dropped again. While in certain cases some changes have indeed been implemented, the militsiya still largely retained its centralised nature, plan-based performance assessment and other features inherited from the Soviet period.

We will not attempt to analyse each of these instances in detail; instead, in this chapter we focus our attention on the two more publicised cases of reforms, namely, the attempt to abolish the traffic police (DAI) in 2005 and the reform of the criminal procedural law in 2012.

\section{Two cases of the previous reform attempts}

The decision to abolish the DAI was taken in the wake of large-scale mass protests in the autumn and winter of 2004, dubbed the Orange Revolution, and subsequent government change. As the law-enforcement agencies were widely associated with an 'old regime' ${ }^{2}$, there existed a significant public pressure to reform them. The choice of the DAI was, in many respects, dictated by the fact that, being a branch of the public service, it had a regular contact with the citizens and was therefore important for image building. At the time, that image was bad: it was considered to be one of the more corrupt services. This

2 One of the points of discontent during the Orange revolution was the Gongadze case. In 2000, Ukrainian journalist Georgiy Gongadze was kidnapped and murdered. In the same year recordings implicating the then incumbent President Kuchma and minister of internal affairs Kravchenko in his disappearance were published, leading to the so-called Cassette Scandal. Four former officials of the Ministry of Internal Affairs were subsequently charged with his murder and sentenced to various terms of imprisonment. Former minister Kravchenko committed suicide not long after the Orange revolution. The case on the Gongadze murder is still open as of September of 2018. 
image primarily originated from the wide-spread practice of accepting and/or soliciting bribes from the drivers in exchange for overlooking traffic violations. Still, it is worth pointing out that the contemporary studies, while confirming a significantly high level of corruption in the DAI, hardly singled out this branch of service as uniquely problematic. For example, Martynenko (2004), surveyed criminal records of the charges filed against the militsiya officers, and showed that while the DAI indeed contributed significantly to the number of criminal cases opened against its officers (58 of 528 in 2002) and the number of officers that were convicted (11 of 78 in 2002), it was hardly the most or the only problematic branch of the police service. For instance, the criminal investigation branch of the militsiya at the same period had 99 cases opened against its officers and 22 officers convicted (Martynenko, 2004: 79).

The reform policy followed on this pressure does not look very consistent. It went as follows. On July 19, 2005, the President issued a decree, ordering the liquidation of the DAI and split it into two separate services: the patrol service and the road militsiya. While the patrol service was indeed established, the DAI itself had never been liquidated, and continued to exist (although in a truncated form). No official explanation had been provided, but already in May 2006, the Minister of Internal Affairs stated that the reform of the DAI had been finished. Despite that, in September of the same year he argued, that the President meant the reform of the DAI, not its liquidation. Thus, the much announced liquidation of the DAI did not happen at that time: it continued to exist, although, with some organisational changes and in a significantly reduced size.

While no reasons were given, the most plausible explanation for not abolishing the DAI, is that due to that lack of planning, sudden changes in the traffic police service would have made driving significantly less safe, increasing the number of traffic accidents. This was emphasized by Zozulia (2008) in his article on this reform. He points out, that according to official data of the Ministry of Internal Affairs, the adopted changes "significantly decreased the efficiency of the DAI" (Zozulia, 2008: 168).

The second intended reform, that of the Criminal Procedural Law in 2012, while not reforming the militsiya directly, affected policing significantly, especially the criminal investigative branch of militsiya. This reform was aimed at replacing the old Criminal Procedural Code, inherited from the Soviet 
times. In this case, the reform showed a much better planning, in both formulating its aims and drafting of relevant bills. Its primary goal was to make the criminal procedure more transparent and fair. It addressed, for example, the issue of the officers refusing to open criminal cases, mentioned as a quite widespread irregularity in the study by Martynenko we quoted earlier (Martynenko, 2004: 79). By making rules of crime registration significantly more stringent such that refused cases surface easier and quicker thereby preventing unaccountable discretion.

It is noteworthy that the second stage of the reform envisioned the adoption of a new classification of criminal offences: there are crimes per se being more serious, and criminal misdemeanours representing petty offences. Consequently, the Criminal Procedural Code provides for much simpler procedures for the investigation of criminal misdemeanours and stipulates the establishment of a separate service to deal with them. However, the provisions of this second stage were adopted only in November of 2018 and will become effective in 2020. Until then, both petty and serious crimes have to be processed by the same criminal procedure, increasing the workload per officer dramatically. Therefore, while the necessity and the conditions of this reform were stated much clearer than for the first one, its implementation stopped halfway, leading to ambivalent results at best. In various branches it increased the workload.

The history of these two policies illustrate a disturbing tendency of the police reforms to either evaporate because of bad planning, unrealistic goals and problems of implementation (as it happened with the DAI), or somewhere in the middle of the process they grind to a halt due to changes in political priorities (as it happened with the reform of criminal proceedings). In addition, to make things worse, virtually every change of the Ministry of Internal Affairs itself went hand in hand with staff reduction, the current police reform not excepted. While, admittedly, some units seemed to have been overstaffed, this correlation between reforms and dismissals did anything but improving the motivation of the officers for further reforms.

Therefore, frequent 'reforms' that brought few improvements to the police, have given rise to an attitude of suspicion to further changes: a mixture of scepticism ("it's just changing a nameplate"), fear for their position and irritation with the meddling from 'above' etc., or, in general, a 'reorganisation fatigue'. 


\section{The Maidan and the current police reform}

The push to the current reform came under tragic circumstances. While there existed a public pressure for comprehensive reforms in 2005, the events of the winter of 2014 made it much more vocal and strong. The events on Maidan led to a critical point, where trust in the law enforcement agencies plummeted, making at least some reaction from the post-revolutionary government necessary. ${ }^{3}$ We should mention, though, that while driving policy-makers to implement police reform, this public pressure also created its own challenges. The necessity to react does not equal to understanding of what kind of a reform is needed. Indeed, the first measures of the new government look like ad hoc decisions; symbolically, one of the first measures taken, in fact, was re-abolition of the DAI (this time, for good).

The objections against the old militsiya system were summarised in the policy document of the current reform, Strategy of the Development of the Agencies of Internal Affairs, adopted by the Cabinet of Ministers of Ukraine on 22 October, 2014. After reflecting upon the role of law enforcement agencies in the tragic events of the winter of 2013-2014, the document stated that "the post-Soviet militarised model of the Ministry of Internal Affairs continued to cultivate an image of an 'exclusive crime fighter', whose success, in general, did not depend on the public support, and whose efficiency was measured by an antiquated system of quantitative indicators of the crime fighting". The document also highlighted such problems as "systematic underfunding", "extensive system of internal corruption", substandard labour conditions and lack of transparency and accountability in the militsiya and Ministry of Internal Affairs in general.

These considerations led to essential differences of the current reform compared to the previous attempts. The first of them is its scope. Where previously reforms were implemented piecemeal, being regulated primarily by the secondary legislation (governmental resolutions, presidential decrees etc.), the current reform envisions a more comprehensive overhaul of the policing

3 The Maidan Revolution is called after the square in the centre of Kyiv, where people came together to protest against President Yanukovc' refusal to sign the Association Agreement with the EU: the Euromaidan movement. In February 2014 this led to serious violence with the riot police followed by the ousting of Yanukovyc. 
praxis, the main points of which have already been enshrined in the new Law on the National Police.

The second difference is that the new law establishes the police as a separate body, under oversight of, but separate from, the Ministry of Internal Affairs. The law stipulates that the main tasks of the police is to provide police services, representing a dramatic shift towards a citizen-oriented policing rather than acting as an agent of state repression. To this end, a new branch of the police has been established: the Patrol Police. This new branch is intended to both bring 'fresh blood' into the force and to open a window to a closer police-citizen cooperation. The establishment of this branch included a wellpublicised recruiting campaign, aimed at inviting young people to serve in the police and promoting reform to the general public.

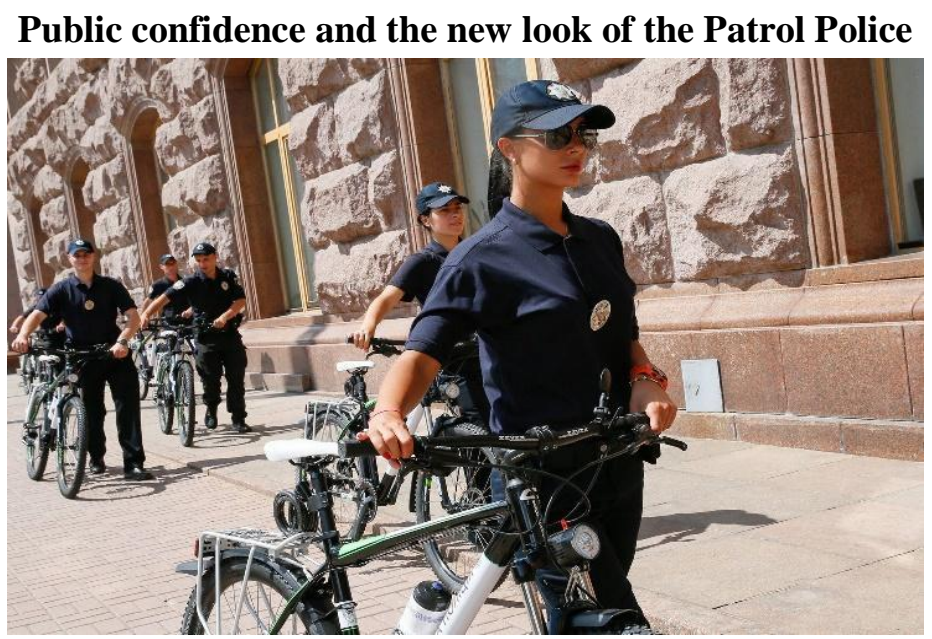

On closer examination, though, the reform suffers from the same slow and often reluctant implementation, as the previous reforms. The most relevant example for us is the intended introduction of the new system of police performance assessment based on public confidence in the police, which is another important dimension of the shift towards a citizen-oriented policing. The law on National Police adopted in 2015 (art. 11 par. 3) stipulates that the level of public confidence in the police is the main criterion of the police performance assessment. The law also stipulates that the level of public confidence is measured by independent sociological services in the manner determined by the Cabinet of Ministers of Ukraine. However, the regulation by the 
Ukrainian government that established procedure for such measurement has only been adopted in the winter of 2018. Therefore, for nearly three years the new system of performance assessment required by the law existed only on paper. In the meantime, the police had either to use the old evaluation system or come up with ad hoc solutions. This ambivalence is at odds with the idea of using the judgments of public opinion as a proper evaluation tool for police performance.

In itself, the direct formulation of this system in the Law on the National Police represents a large step forward. This idea, of course is hardly new in the 'West'; neither is it new for the Ukrainian academia. Publications presenting public opinion as an important source for police performance evaluation existed as early as in 2005 (e.g., Maltsev, 2005).

Despite this lacuna, a series of surveys in the Kharkiv Region spanning 2013-2018 should be mentioned (Serdyuk, 2018: 45). In 2013, the percentage of those who trusted or "somewhat trusted" their local pre-reform militsiya division in the region was 24 and $39 \%$ opposed to 10 and $13 \%$ of those who distrusted or 'somewhat' distrusted it.

By 2018 only 15\% trusted the police with additional 40\% "somewhat" trusting it. On the other hand, the percentage of those who distrusted or "somewhat" distrusted it decreased slightly to 6 and 11\%. Asked specifically about the trust to their local Patrol Police (ibid.: 50), 11\% stated they trusted it, $45 \%$ "somewhat" trusted the new division; 3 and 11\% distrusted or "somewhat" distrusted it. While we must caution, that this survey represents only one region of Ukraine, it shows that the reform still has a long way to go before it reaches its goals in building public trust in the police.

On the whole, the current reform is not doomed to failure by itself. Nevertheless, its implementation shares much of the same characteristics, which led to the less than spectacular results. One of them, arguably, is lack of regard by the policy makers of the effects that reforms have on the day-to-day tasks and working conditions of the police officers. How do they experience these changes? As they have to carry out the reform, it is important to learn their perceptions. Another important reason to gauge the perception of the reform by the police officers is, of course, the fact that the aforementioned shift towards more citizen-oriented policing depends largely on the rank-and-file making efforts to implement these changes in their day-to-day work. This led to the research question of how the goals and changes due to this reform are perceived by the police officers. 


\section{Methodology}

\section{Questionnaire and data collection}

From spring to autumn 2017 a survey was conducted which included the use of two data collection methods:

1. Web-based survey on the Qualtrics online survey platform in spring 2017 resulting in 194 responses;

2. Face-to-face interviews during the autumn 2017, with a structured paper questionnaire filled by 385 respondents personally and anonymously. The participation was voluntary.

The composition of the paper questionnaire consisted of 41 closed questions (indicators) with 75 items (generally Likert type ordinal or interval scales). The web-based questionnaire included additional open-ended questions, the Herzberg motivational scale and personality questionnaire Big Five Inventory (BFI-10). The outcomes of these additional subjects are not discussed in this paper.

In this paper we focus on respondents' answers concerning the following clusters of content:

1. The respondents' perception of the police reform with an emphasis on the interaction with the public;

2. The respondents' perception of the police organisation as a 'fair employer', particularly where it concerns the protection of social and labour rights;

3. Working conditions as a background, comprising salary as well as the availability of office facilities and tools. ${ }^{4}$

For the processing and analysis of data the statistical software package SPSS Statistics v.25 and Microsoft Office Excel were used.

This survey built on preceding investigations carried out between 2013 and 2017 as mentioned above. In these surveys, respondents from the police had been asked to express their opinion about the importance of public trust for the police. Now police officers were asked to formulate their perception of their interactions with the public as well as their view on the police reform and their police organisation.

4 An analysis of the full range of questions will be provided by the final report of 344 this project. 


\section{The sample}

The intended sample size was 500, but in the end, a sample size of 552 was achieved. The determination of the intended sample size was based on the data about number of police officers per branch and a previously conducted research project in 2007 devoted to the same topic: the police reform and social guarantees for the police. The approximate number of police officers in 2017 was 8000 and for the end of 2018 it was reduced to $7.892 . .^{5}$ The number of patrol police officers by staffing schedule in 2017 is 1.478 , but the actual number in 2018 was $1.359 .{ }^{6}$ Our total sampling population is approximately 9.300 . The number of selected respondents per branch is based on the estimate of the general number of positions per specific branch. An estimate is necessary here, because the police service in the Kharkiv region does not provide public information about the number of actually employed officers by specific branch. The approximate sampling characteristics were kept similar to those of the 2007 research project in order to enable the comparison between the 'old' militia and the 'new' police force (Bielousov, Kobzin, Sviezhentseva, Serdyuk et al, 2008). The adoption of the face-to-face paper-based method of data collection in the second stage of research was made necessary because of the low response rate achieved in the web-based survey.

The sampling method implemented in this study is a Quota sampling per branch of police service. We use only one inclusion criterion for the subsets of participants: the branch of the police service. There is no exclusion criteria or any restrictions based on demographic or socio-economic characteristics (e.g., age, sex, ethnicity, socioeconomic status).

The sample from the Ukraine National Police of the Kharkiv region consists of the following branches which participated in the survey.

5 From official website https://hk.npu.gov.ua/about/struktura/shtat-ta-chiselnist.html

6 From the response for official letter: https://ukr.lb.ua/news/2019/01/16/417300_nedokomplekt_patrulnoi_politsii.html?fbclid=IwAR $1 \mathrm{uQHR}$ GfCfeEr75Cq2dLfU3Itj_pxgA65jbEXaj0dq0MYzxqjvWlkciTlg 
Table 1

Respondents by branch of service according to the 2017 questionnaire

\begin{tabular}{|l|c|c|}
\hline Type police service & Frequency & Valid \% \\
\hline Criminal police & 114 & 21,3 \\
\hline Pre-trial investigation & 47 & 9,5 \\
\hline Department for prevention & 46 & 9,3 \\
\hline Regional Police Directorate & 42 & 8,5 \\
\hline SWAT* $^{*}$ & 23 & 4,7 \\
\hline Battalion Kharkiv* & 25 & 5,1 \\
\hline East Oriental Corps* & 25 & 5,1 \\
\hline Other division Pol & 27 & 5,5 \\
\hline Patrol Police & 144 & 29,2 \\
\hline Total & 493 & 100,0 \\
\hline
\end{tabular}

Missing values: 59

*In the later analysis the Battalions and the SWAT have been dropped after an initial test: they have more defence tasks and little interaction with the public.

From the reform perspective (more citizen orientation of the police), the most important division is between the Patrol Police and the other service branches: the Patrol Police is intended to have more direct interaction with the people. This branch has its own chain of command and is not a part of the Regional Directorates that act as territorial branches of the police at the oblast level. This does not imply that the other branches were not touched by the police reform. Changes in education and health care are mentioned as well as the bringing together of the functions of operations officers and criminal investigators. How deep that reform penetrated into the branches other than the Patrol Police is difficult to determine. Some experiments, such as crime mapping, have been carried out in these branches, but systematic surveys or evaluation of these changes are lacking. Although in the police reform the Patrol Police has a special place, we will compare their perceptions and background variables of its officers with those of the staff of the other branches. 


\section{Findings}

\section{a. Perception of the police reform by officers}

\section{Understanding and the 'right direction'}

The first question concerns the general level of understanding of the reform: its tasks and objectives as far as the respondents themselves declared to understand the reform, whether fully, partly or not at all. As this implies some scale of understanding, we designed the following levels of understanding scale:

- Completely understand the reform

- Understand the reform somewhat

- Somewhat don't understand it

- Don't understand the reform at all

Naturally, the two middle categories are fluid, but they still represents the opinion of the respondent of what he or she thinks to understand. We did not examine his or her real knowledge of the reform, only their perception of their understanding.

\section{Table 2}

Self-assessed understanding within the police branches.

\begin{tabular}{|c|c|c|c|c|c|c|c|c|}
\hline Police branch & & Pre- & & Reg. & & Other & & \\
\hline $\begin{array}{l}\text { Level of un- } \\
\text { derstanding }\end{array}$ & $\begin{array}{c}\text { Crime. } \\
\text { police } \\
\%\end{array}$ & $\begin{array}{c}\text { trial } \\
\text { invest. } \\
\% \\
\end{array}$ & $\begin{array}{c}\text { Preven- } \\
\text { tion } \\
\%\end{array}$ & $\begin{array}{c}\text { pol. } \\
\text { direct. } \\
\% \\
\end{array}$ & $\begin{array}{c}\text { Patrol } \\
\text { Police } \\
\% \\
\end{array}$ & $\begin{array}{l}\text { divi- } \\
\text { sion } \\
\%\end{array}$ & $\begin{array}{l}\text { Total } \\
\mathrm{N}\end{array}$ & $\%$ \\
\hline Completely & 33 & 33 & 30 & 36 & 54 & 37 & 168 & 40 \\
\hline $\begin{array}{l}\text { Somewhat } \\
\text { yes }\end{array}$ & 12 & 16 & 35 & 26 & 24 & 41 & 93 & 22 \\
\hline Diff to answer & 26 & 36 & 22 & 19 & 13 & 11 & 85 & 20 \\
\hline Somewhat no & 20 & 11 & 11 & 12 & 8 & 11 & 53 & 13 \\
\hline Not at all & 9 & 4 & 2 & 7 & 1 & 0 & 18 & 4 \\
\hline Total $=100 \%$ & 114 & 45 & 46 & 42 & 143 & 27 & 417 & 100 \\
\hline Missing 62 & & & & & & & & \\
\hline Index* & 1.92 & 2.21 & 2.19 & 2.12 & 2.49 & 2.29 & 2.27 & \\
\hline
\end{tabular}

*For the illustrative purposes, we converted percentages into indices on the scale from 0 to 3 (don't understand $=0$, rather don't understand $=1$, somewhat understand $=2$, understand completely $=3$, in order to prevent dilution of the index, the option 'difficult to answer' was treated as a missing value). 
It is essential that the police officers across all branches of service have at least some knowledge of the reform and its goals as they are the ones who will, ultimately, implement its principles in their daily work. In the case of the Patrol Police, a high level of understanding follows logically from the fact that this branch was established in the course of the reform; additionally, the training of the recruits for the Patrol Police included explanation of the goals of the police reform. Table 2 provides an overview of the police branches and the self- assessment of understanding. As the Table indicates most respondents think they have a fair (22\%) to a full understanding (40\%) of the reform process. This score is somewhat veiled because $20 \%$ of the respondents found it difficult to answer this question. This option was inserted for the respondents who do not feel that they can express their opinion or knowledge of the reform coherently.

Apart from that, most Patrol Police officers rated the assessment of their knowledge complete (54\%) or more or less sufficient (24\%). The next highly self-assessing categories are the division of pre-trial investigation $(33 \%$ full understanding and $16 \%$ rather well understanding) and department of prevention (30\% full understanding and 35\% rather well understanding). Both have a significant score of "difficult to answer", however.

This self-assessment of understanding gains meaning if connected to a number of functional 'features' of the respondents: age, length of service or kind of police division or education. Is there a relation between length of service or age of the respondents? There was indeed a small but significant 'age' or 'years of service' effect on the understanding levels: the group that expressed complete understanding has a mean age of 30,3 years compared to 33 years in the category of "not understand at all": an inverse significant correlation between age and expressed level of understanding $(r=-0,117$; sign. 0,001 , two sided). The same observation is made concerning the length of service, which as a time variable is not independent from the basic age variable. Indeed, there is again an inverse relation between service time and understanding: respondents reporting a "complete understanding" have an average service length of 8,6 years, compared to 11,5 years for the 'not-understanding' group and 12,9 service years for the 'not fully understand' group. So there is a length-of-service effect in the understanding of the reform, but again the correlations are small, though statistically significant (Spearman rho $=-0,197$; 0,001 two sided). 
The following question of interest concerns the perceived change: reform without awareness of change does not look very satisfying. However, the general 'change perception' may conceal the more specific effects on various aspects of the police tasks and organisation.

Table 3.

What changes did the reform bring to your work?

\begin{tabular}{|l|c|c|c|c|c|c|c|c|}
\hline & $\begin{array}{c}\text { Sign. } \\
\text { impr. } \\
\%\end{array}$ & $\begin{array}{c}\text { Some } \\
\text { impr. } \\
\%\end{array}$ & $\begin{array}{c}\text { No } \\
\text { change } \\
\%\end{array}$ & $\begin{array}{c}\text { Little } \\
\text { worse } \\
\%\end{array}$ & $\begin{array}{c}\text { Sign. } \\
\text { worse } \\
\%\end{array}$ & $\begin{array}{c}\text { Hard } \\
\text { to an- } \\
\text { swer } \\
\%\end{array}$ & Ind.* & $\begin{array}{c}\text { Total } \\
\text { N= } \\
100 \%\end{array}$ \\
\hline $\begin{array}{l}\text { Organisation } \\
\text { of work }\end{array}$ & 21 & 28 & 30 & 7 & 8 & 7 & 0.25 & 473 \\
\hline Legal frame & 10 & 23 & 37 & 9 & 15 & 5 & 0.02 & 466 \\
\hline Coop. police & 12 & 24 & 37 & 8 & 16 & 3 & 0.05 & 465 \\
\hline $\begin{array}{l}\text { Coop. publ. } \\
\text { agencies }\end{array}$ & 10 & 20 & 47 & 8 & 10 & 5 & 0.07 & 473 \\
\hline Coop. citiz. & 9 & 18 & 48 & 8 & 10 & 7 & 0.05 & 470 \\
\hline Salary & 14 & 23 & 41 & 8 & 10 & 4 & 0.12 & 464 \\
\hline Supplies & 15 & 36 & 21 & 8 & 13 & 6 & 0.17 & 469 \\
\hline $\begin{array}{l}\text { Social guar- } \\
\text { antees }\end{array}$ & 5 & 8 & 44 & 10 & 26 & 7 & -0.25 & 466 \\
\hline $\begin{array}{l}\text { Legal safe- } \\
\text { guard }\end{array}$ & 5 & 6 & 42 & 10 & 30 & 7 & -0.29 & 469 \\
\hline Average & 11 & 21 & 39 & 8 & 15 & 6 & & \\
\hline
\end{tabular}

*For illustrative purposes, we converted percentages into indices on the scale from -1 to 1 (significant worsening $=-1$, some worsening $=-0.5$, no change $=0$, some improvement $=+0.5$, significant improvement $=+1$, in order to prevent dilution of the index, the option 'hard to answer' was treated as a missing value).

The first interesting finding is that on average 39\% of the respondents thought they experienced no change in their organisation or their working environment. There is one exception: the provision of supplies. Supplies, in this case, mean all the equipment and facilities necessary for the police officers to perform their duties (See Table 10). For 51\% of the respondents this implied an improvement: for $15 \%$ a significant one and for $36 \%$ only a minor improvement. Still, 21\% noticed a worsening.

Most approval was expressed concerning the organisation of their work: $21 \%$ observed a significant and 20 some improvement; the Patrol Police being most satisfied (65\%) and the Department of Prevention least (33\%). 
The outcomes of the cooperation variables, one of the targets of the reform project (cooperation with other police forces, public agencies and the citizens) do not seem to meet expectations. On average $44 \%$ saw no change: least with the citizens' cooperation (48\%) and best regarding the cooperation with other police forces, though most respondents rated this change rather modestly (24\% 'somewhat'; $12 \%$ 'significantly').

It should be noted that most respondents did not express much satisfaction about personal guarantees, whether social or legal. Around $44 \%$ saw no change and on average $26 \%$ mentioned even a significant worsening.

Using the index values to gauge perception of the changes by the different branches of service, yielded the following picture. Officers from the Patrol Police were the most satisfied about changes to the organisation of work $(0,42)$, legal framework $(0,15)$, cooperation with other police divisions $(0,28)$, cooperation with other public agencies $(0,17)$, cooperation with the citizens $(0,16)$, salary $(0.24)$ and supplies $(0,22)$. When it comes to the spheres where the majority of the respondents claimed deterioration (social and legal guarantees), the least dissatisfied were respondents of the Pre-trial Investigation ($0,15)$ and department of prevention $(-0,19)$ respectively. In general, it seems that the Patrol Police tend to regard the changes better than their colleagues. This also corresponds with the breakdown of the index values by the length of service. Officers with the shorter term of service (especially those serving less than 3 years) tend to view changes more positively than the officers who served longer. This can be contributed to the Patrol Police officers' average years of service: 5 years compared to 10 years of the whole sample. The notable exception is the situation with the supplies, where, in fact, the officers who served more than 20 years showed the largest value of the index.

These findings raise the question whether the respondents consider this project going into the right direction. Taken all the respondents together, one third thought the reform went fully or partly into the right direction. Another third thought the opposite, while 32\% thought it difficult to answer this question. To what extent this affected the motivation is not easy to determine. Staying or leaving the police force may be an indicator of motivation. One would expect that those who thought the project went into the wrong direction would more frequently say that they would leave the service. In fact, there was such a tendency: respondents who questioned the right direction also indicated a bigger willingness to leave the police in the coming 1-3 years. However, the 
correlation (Spearman rho) between these variables is low $(0,108)$ but just significant $(0,025)$. Indeed, the opinion about the direction seems to yield little more than this trend.

As the participating police branches may have different interests, we inspected the outcomes of the 'branch of service' variable. In total, only $8 \%$ of the respondents thought the project was going into the right direction, with little variation between the police units (range: 6\% Patrol Police and 9\% pretrial investigation). $24 \%$ thought the project went 'rather or somewhat' into the right direction, a modest judgement. A large part of the Patrol Police (38\%) expressed this meagre valuation, followed by the pre-trial investigation (24\%). There is a confusing 'knowledge effect' already presented in Table 2: of the 75 respondents who said they did not (fully) understand the project, 59 (79\%) of them still thought it did not go into the right direction. This, however, could be explained by the fact that, while these officers do not understand the reform, they still feel its consequences in their day-to-day jobs, which they do not like or, otherwise, do not see any changes they would expect from the reform.

It should be noted that around a third of the respondents did not know how to answer these questions. This is in contrast to the relatively low percentage of the officers who did not know how to answer the questions about the specific changes to their work, ranging only from 3 to $7 \%$ (see Table 4). One possible interpretation of this phenomenon could be that instead of the big picture, envisioned by the authors of the reform, police officers themselves are more focused on the more mundane aspects of their job.

\section{Perception of police tasks and citizens}

Having surveyed the officers' understanding of the reform project and the evaluation of its direction, the question should be raised how this relates to one of the key objectives: increasing public confidence in the police. By the nature of this survey - police perceptions - this relationship cannot be assessed directly as the research project does not contain a parallel citizen opinion survey. Instead, the respondents were asked whether they were of the opinion that public trust in the police is an adequate criterion to assess the officers' work. This question relates closely to the understanding of the reform by police officers, as reorienting policing towards a more service-based model is one of the basic principles of the reform. The respondents answered to this question 
relatively positive: $17 \%$ thought that this was "completely" the case and $31 \%$ "to a certain extent". However, $20 \%$ thought that the public trust is rather not an indicator of the efficiency of policing, and $6 \%$ strongly disagreed with the notion that their work can be adequately assessed by measuring the public trust.

This is a positive finding, which should also be reflected in the related ' $\mathrm{co}$ operation with citizen' variable as presented in Table 4 . However, only $9 \%$ of the respondents answered positive to this related question about 'citizen cooperation': $9 \%$ thought it "significantly improved" and 18\% "somewhat". That is moderate compared to the finding that $48 \%$ of the respondents reported no change while $18 \%$ saw the cooperation worsening (7\% could not answer this question). For this reason, we combined the two variables and calculated their correlation. The cross-tabulation is presented in Table 4. It reveals a tendency to rate the importance of the public confidence higher when there is also a significant improvement in cooperation as indicated. However, there were many respondents who felt on the one hand, that public trust adequately assesses the quality of their work, while on the other hand, that the cooperation with the citizens had become worse. Indeed, the Spearman's rho correlation is weak, though statistically significant $(0,149 ; 2$ tailed significant 0,002$)$. Some of the branches differed widely on this variable: for example, $18 \%$ of the Criminal Police mentioned a significant worsening of the cooperation but $31 \%$ of the Patrol Police noted some improvement and $11 \%$ a significant improvement.

\section{Table 4}

Cooperation police-citizen by reflected confidence

\begin{tabular}{|c|c|c|c|c|c|c|c|c|}
\hline Coop. Cit. & Sign. & Insign. & No & Little & Much & Diff. & Total & \\
\hline Confidence & $\begin{array}{c}\text { impr. } \\
\%\end{array}$ & $\begin{array}{c}\text { impr. } \\
\%\end{array}$ & $\begin{array}{c}\text { change } \\
\%\end{array}$ & $\begin{array}{c}\text { worse } \\
\%\end{array}$ & $\begin{array}{c}\text { worse } \\
\%\end{array}$ & $\begin{array}{c}\text { to an- } \\
\text { swer } \\
\%\end{array}$ & $\mathrm{~N}$ & $\%$ \\
\hline Sign. impr. & 34 & 19 & 15 & 6 & 7 & 0 & 72 & 16 \\
\hline Insign. impr. & 31 & 45 & 32 & 15 & 24 & 14 & 143 & 32 \\
\hline $\begin{array}{l}\text { Diff. to an- } \\
\text { swer }\end{array}$ & 21 & 18 & 27 & 45 & 27 & 50 & 118 & 26 \\
\hline Little worse & 9 & 12 & 24 & 27 & 30 & 29 & 92 & 20 \\
\hline Much worse & 4 & 7 & 4 & 6 & 11 & 7 & 25 & 6 \\
\hline Total $=100 \%$ & 56 & 108 & 169 & 33 & 70 & 14 & 450 & 100 \\
\hline$\%$ & 12 & 24 & 38 & 7 & 16 & 3 & 100 & \\
\hline
\end{tabular}

Missing values: 29 
We may conclude that the respondents were moderately satisfied with the improvement of cooperation and that there are reasons to deduce that this influences their acceptance of the importance of the public trust in their work. However, the relation is not that strong that it justifies the assumption of a stronger causality.

The questionnaire also asked for other facets of the police citizen interaction, as far as perceived by the respondents. Two questions addressed two almost opposing motivations or responses related to the public-police interaction: (1) avoiding complaints from the citizens and (2) gaining approval by the citizens.

In the first case, we can assume that the importance of gaining trust from citizens translates into the professional and proper conduct that avoids evoking complaints. Indeed, 130 respondents (28\%) indicated that in their work they "keep this constantly in mind". 114 respondents (24\%) said to have this principle "often in mind". Both subsets were also sensitive to what we call the 'confidence effect', as presented in Table 5.

\section{Table 5}

Avoiding complaints broken down by citizens' confidence

\begin{tabular}{|c|c|c|c|c|c|c|c|}
\hline $\begin{array}{r}\text { Avoid com- } \\
\text { plaint }\end{array}$ & Constantly & Often & Rarely & Never & $\begin{array}{l}\text { Diff. to } \\
\text { answer }\end{array}$ & Total & \\
\hline Confidence & $\%$ & $\%$ & $\%$ & $\%$ & & $\mathrm{~N}$ & $\%$ \\
\hline Completely & 25 & 12 & 14 & 18 & 6 & 75 & 16 \\
\hline Somewhat & 31 & 38 & 35 & 16 & 25 & 143 & 31 \\
\hline $\begin{array}{l}\text { Diff. to an- } \\
\text { swer }\end{array}$ & 21 & 28 & 28 & 19 & 47 & 121 & 26 \\
\hline Rather not & 21 & 17 & 18 & 32 & 17 & 93 & 20 \\
\hline Not at all & 3 & 5 & 4 & 14 & 6 & 6 & 6 \\
\hline Total & 130 & 114 & 116 & 62 & 36 & 458 & 100 \\
\hline$\%$ & 28 & 24 & 25 & 14 & 8 & 100 & \\
\hline
\end{tabular}

Missing values: 21

More than half of the 130 respondents who said to avoid complaints from citizens were aware of the importance of the public confidence $(25 \%$ "completely" and 31\% "somewhat"). However, $14 \%$ of the respondents who rarely paid attention to avoiding complaints still reported they "completely" thought the public confidence is an important yardstick of their work, with another $35 \%$ of this subset stating it is a "somewhat" important yardstick. Indeed, the 
correlation of the complaint variable with the public confidence variable is low: Spearman rho, 0,153 , though 0,001 statistically significant. A similar low correlation is found with the cooperation variable of citizens with the police: Spearman rho, 0,117 , significant at 0,013 .

Relating the avoidance variable to the particular branches of service, it was observed that the Criminal Police was most keen to avoid complaints: 56\%; the Department of Prevention the least: $31 \%$. This may be a function of the kind of tasks these branches perform, however. The Criminal Police, acting under the stringent rules of criminal procedure, face much more significant risks because of citizens' complaints, than the Prevention Department, whose officers more often deal with administrative cases.

A stronger correlation was found between the perception of public confidence and the need to obtain positive feedback from citizens: Spearmen rho 0,272 ; significance 0,000 . Those who were most sensitive to public confidence (59\% 'completely') were constantly aware of the need of positive feedback. However, $33 \%$ who said they rather did not think of public confidence still were constantly aware of the need of positive feedback. Between the need of feedback and kind of service there was no significant correlation.

\section{Table 6}

Citizens' confidence broken down by need of positive feedback

\begin{tabular}{|c|c|c|c|c|c|c|c|}
\hline $\begin{array}{c}\text { Citizens' } \\
\text { confidence }\end{array}$ & $\begin{array}{c}\text { Completely } \\
\%\end{array}$ & $\begin{array}{c}\text { Somewhat } \\
\%\end{array}$ & $\begin{array}{c}\text { Diff. to } \\
\text { answer } \\
\%\end{array}$ & $\begin{array}{c}\text { Rather } \\
\text { not } \\
\%\end{array}$ & $\begin{array}{l}\text { Not } \\
\text { at all } \\
\%\end{array}$ & $\begin{array}{c}\text { Total } \\
\mathrm{N}\end{array}$ & \\
\hline $\begin{array}{l}\text { Need feed- } \\
\text { back }\end{array}$ & & & & & & & $\%$ \\
\hline Constantly & 59 & 28 & 25 & 33 & 15 & 148 & 33 \\
\hline Often & 25 & 49 & 29 & 22 & 23 & 149 & 33 \\
\hline Rarely & 13 & 18 & 29 & 23 & 35 & 100 & 22 \\
\hline Never & 0 & 4 & 6 & 16 & 19 & 32 & 7 \\
\hline $\begin{array}{l}\text { Diff. to an- } \\
\text { swer }\end{array}$ & 3 & 2 & 11 & 7 & 8 & 26 & 6 \\
\hline Total & 75 & 144 & 118 & 92 & 26 & 455 & 100 \\
\hline$\%$ & 16 & 32 & 26 & 20 & 6 & 100 & \\
\hline
\end{tabular}

Missing values 24

In general, the respondents displayed an awareness of the public confidence as a reflection of the quality of their professional conduct, the importance to 
avoid complaints and the importance of feedback. However, we have no yardstick to determine whether this is a result of the police reform itself. The highest score of "completely reflects police conduct" with $16 \%$ of the respondents (see Table 6, first column) is certainly modest. The other variables have a higher score, but the correlations between the variables is modest. Though there is a tendency, there is certainly no clear pattern, let alone a causality.

\section{Some material and organisational background facets}

While the targets of the police reform are to a large extent of a social, organisational and institutional (cooperation with other police forces and civil institutions) nature, attention should also be devoted to the perception of the facets of the tangible working environment. Though officers may rationally recognise the need for reform and express their appreciation of many positive aspects, their perception of the working environment may have more influence on their motivation than politically correct statements about reform themes. Moreover, as observed earlier, police officers tend to have opinions that are more related to the day-to-day job conditions than to the more general aspects of the reform.

This is a broad angle, which for the purpose of this chapter must be narrowed to what we assume is motivationally relevant. Two aspects stand out:

a. Material and legal labour conditions;

b. Protection of health and position.

The distinction is a matter of convenience: protection can be interpreted as a labour condition and the other way round.

\section{a. The perception of material and legal working conditions}

Obviously, the general perception of working conditions are important: it is the 'mental frame', within which other perceptions are ordered. In this research, the mental frame consists of the answers to the question about fair labour conditions. The majority of the answers to this question pointed clearly into one direction: of the 443 respondents 170 said they experience "no" and 95 "rather no" fair labour conditions (38\% and 21\%). Only 38 (9\%) rated their labour conditions as fully fair. Asked for more precision $71 \%$ stated that they think their social and labour rights are violated. 
A fairly strong correlation was found between the perception of the fairness of the working conditions and the perception of the violations of labour and social rights: Spearmen rho $-0,468$; significance $0,000.82 \%$ of those who consider their working conditions unfair responded also that their labour and social rights are violated; of those who consider their working conditions fair only $26 \%$ reported no labour and social rights violations (with an additional $18 \%$ responding "somewhat no").

Table 7

Fairness of labour conditions against

labour and social rights violations

\begin{tabular}{|c|c|c|c|c|c|c|}
\hline Fair conditions & Yes & Somewhat & Somewhat & Not & Total & \\
\hline Rights violated & $\%$ & $\%$ & $\begin{array}{l}\text { no } \\
\%\end{array}$ & $\begin{array}{c}\text { at all } \\
\%\end{array}$ & & $\%$ \\
\hline Yes & 21 & 16 & 34 & 82 & 148 & 38 \\
\hline Somewhat & 34 & 38 & 42 & 13 & 149 & 34 \\
\hline Somewhat no & 18 & 43 & 22 & 1 & 100 & 24 \\
\hline No & 26 & 4 & 2 & 4 & 32 & 5 \\
\hline Total & 38 & 140 & 170 & 95 & 446 & 100 \\
\hline$\%$ & 9 & 32 & 38 & 21 & 100 & \\
\hline
\end{tabular}

Missing values: 33

\section{a1. Getting paid}

We assume that one type of violations of rights impacting directly on the officers' perception concerns the payment of salaries: do they get their full legal pay? This question was answered negatively by $29 \%$ of the respondents while $45 \%$ said they did not know, both remarkably high numbers for this important labour condition. Still it may even be flattering, given the finding that $96 \%$ respectively $94 \%$ does not get full compensation for overtime or night-time work even if it is compensated by extra days off. But what if these days off accumulate endlessly?

Income, as a component of the material working conditions is important in another way: many officers reported difficulties of making ends meet, as presented in Table 8 . 


\section{Table 8}

Salary improvement by 'sufficient salary to maintain family'

\begin{tabular}{|l|c|c|c|c|c|c|c|c|}
\hline \multicolumn{1}{|c|}{ Improvement } \\
$\begin{array}{l}\text { Sufficient } \\
\text { salary }\end{array}$ & $\begin{array}{c}\text { Sign. } \\
\text { impr. } \\
\%\end{array}$ & $\begin{array}{c}\text { Insign. } \\
\text { Impr. } \\
\%\end{array}$ & $\begin{array}{c}\text { No } \\
\text { change } \\
\%\end{array}$ & $\begin{array}{c}\text { A bit } \\
\text { worse } \\
\%\end{array}$ & $\begin{array}{c}\text { Sign. } \\
\text { worse } \\
\%\end{array}$ & $\begin{array}{c}\text { Diff. to } \\
\text { answer } \\
\%\end{array}$ & $\begin{array}{c}\text { Total } \\
\mathrm{N}\end{array}$ & $\%$ \\
\hline Yes & 15 & 7 & 1 & 0 & 7 & 6 & 21 & 5 \\
\hline Rather yes & 12 & 12 & 9 & 9 & 13 & 6 & 43 & 10 \\
\hline Rather no & 30 & 33 & 35 & 46 & 22 & 25 & 138 & 33 \\
\hline No & 44 & 48 & 55 & 46 & 58 & 63 & 219 & 52 \\
\hline Total N=100\% & 61 & 87 & 177 & 35 & 45 & 16 & 421 & \\
\hline In \% & 14 & 21 & 42 & 8 & 11 & 4 & & \\
\hline
\end{tabular}

Missing values: 58

As can be deduced from Table 8 , the salaries tend to be generally perceived as insufficient income to maintain a family, even though $44 \%$ of the surveyed officers report a significant improvement in the salary. On the whole, $85 \%$ thought the pay was insufficient to maintain a family, whether an improvement was mentioned or not. The Patrol Police seems to have gained most: $51 \%$ of them mentioned an improvement in salary against only $20 \%$ of the Criminal Police.

Not surprisingly, respondents generally declared modest living expenses in their households. 58\% stated that they spend all their money on basic, inexpensive goods, 29\% - that while their households' income was generally sufficient, it was still difficult to purchase some goods, such as furniture, TV, refrigerator etc. $9 \%$ claimed that they don't have enough money even for the most essential goods.

\section{a2. Feeling protected}

Another matter concerns the feeling of being protected. This issue has many facets, which are part of the general perception of the protection of human rights and freedoms in Ukraine. Within this broader framework, we project the perceptions of protection derived from specific regulations such as the regulatory framework of the use of force, and weapons training. Protection of police officers also concerns their rights and freedoms in relation to citizens as well as their protection in court: do police officers enjoy the same protection as citizens? 
Going from the broadest protection circle and narrowing our focus, we find that the respondents' perception of human rights protection in Ukraine does not reflect much trust: $43 \%$ thought the protection in general not sufficient and $9 \%$ completely absent. Does this have any influence on the perception of the reform? In focus groups it was mentioned that protection of rights is an important issue for police officers. These frequently mentioned concerns were converted into specific survey questions relating to officer-citizen legal interactions, for example, who "enjoys better protection: the police officer or a common citizen?" Obviously, there should be equality of justice, but perception may be different as presented in Table 9 .

\section{Table 9}

Perception of equality of legal protection of citizens and police officers: In general and at trial

\begin{tabular}{|l|c|c|}
\hline Equality in protection? & $\begin{array}{c}\text { General protection } \\
\%\end{array}$ & $\begin{array}{c}\text { At trial } \\
\%\end{array}$ \\
\hline Police more than citizen & 1 & 2 \\
\hline Equally & 22 & 28 \\
\hline Citizen more than police & 77 & 71 \\
\hline $\mathrm{N}=100 \%$ & 479 & 479 \\
\hline
\end{tabular}

The answers to these specific questions point clearly into one direction: officers feel that in legal proceedings with citizens there is a preferential treatment of the citizens. This perception is expressed in all services, independent of the perceived level of social protection and the kind of service.

One may hypothesise that trust in a fair employer may act as a counterbalance to this bias such that officers may generally feel socially protected. In the perception of the respondents that appeared not to be the case. $60 \%$ of the respondents do not consider the police organisation a fair employer $(41 \%$ a bit unfair and $20 \%$ not fair at all) and $83 \%$ feel to be "rather not" or "not at all protected'. 


\section{Table 10}

\section{Police organisation as employer and sense of social protection}

\begin{tabular}{|c|c|c|c|c|c|c|}
\hline Fairness employer & Fair & Somewhat & Somewhat & Not fair & & \\
\hline Socially protected & $\%$ & $\%$ & $\%$ & $\%$ & $\mathrm{~N}$ & $\%$ \\
\hline Yes & 27 & 2 & 1 & 1 & 16 & 4 \\
\hline Somewhat yes & 21 & 22 & 9 & 1 & 53 & 12 \\
\hline Somewhat not & 32 & 53 & 52 & 20 & 189 & 44 \\
\hline No & 21 & 23 & 39 & 78 & 169 & 40 \\
\hline $\mathrm{N}=100 \%$ & 44 & 126 & 176 & 81 & 427 & \\
\hline$\%$ & 10 & 30 & 41 & 20 & & \\
\hline
\end{tabular}

Missing values: 52

As can be observed, the perception of not being protected is predominant. Even among the respondents who think the police organisation a fair employer, more than half (53\%: that is $32 \%$ "somewhat" plus $21 \%$ "not at all") have (severe) doubts about their social protection. However, this is only a small subset of the population: the vast majority doubts the fairness of the employer as well as the prospect of proper protection.

Many facets of the police work entail the risk of getting harmed, physically or mentally, against which the police organisation is required to provide protection. As protecting health and safety may in actual work situations be complex we also asked the respondents whether they got sufficient training on this point. This proved to be the case: $72 \%$ thought they had either "fully sufficient" $(18 \%)$ or "generally sufficient" $(54 \%)$ training to protect their health. However, when it came to actual sickness, only $4 \%$ said that the necessary treatment was provided, while $84 \%$ said that this did not happen: "fully" $53 \%$ or "not fully" $31 \%$.

\section{a3. Being supplied}

Against the background of the perception of the fairness of the police organisation it is of importance to take stock of the provisions, facilities and tools needed for the execution of police tasks, as is becoming of a good and fair employer in the implementation of an important reform. Formulated simply: what is the point of reform if in the end you still sit on wooden boxes in an unheated office with no gas for the car to do patrols? This question is not new: in the 2007 survey (Bielousov, 2008) there was also a question about material 
provisions of officers in their stations. We provide the findings of 2007 together with those of 2017 , obviously with warnings of methodological caveats. $^{7}$ The comparison is only partial because some of the implied services no longer exist. Despite these differences, the figures give an indication of changes over time.

Table 11

Equipment and provisions of police stations: 2007 and 2017

\begin{tabular}{|c|c|c|c|c|}
\hline & Year & $\begin{array}{l}\text { Sufficiently } \\
\text { provided }\end{array}$ & $\begin{array}{l}\text { Partially } \\
\text { provided }\end{array}$ & $\begin{array}{l}\text { Not pro- } \\
\text { vided }\end{array}$ \\
\hline \multirow{2}{*}{ Workplaces } & 2017 & 42 & 41 & 17 \\
\hline & 2007 & 48 & 43 & 10 \\
\hline \multirow{2}{*}{ Stationery } & 2017 & 16 & 38 & 47 \\
\hline & 2007 & 11 & 27 & 63 \\
\hline \multirow{2}{*}{ Means of communication } & 2017 & 18 & 46 & 36 \\
\hline & 2007 & 32 & 47 & 21 \\
\hline \multirow{2}{*}{ Computers } & 2017 & 15 & 49 & 36 \\
\hline & 2007 & 13 & 49 & 38 \\
\hline \multirow{2}{*}{ Internet access } & 2017 & 26 & 37 & 37 \\
\hline & 2007 & 9 & 21 & 70 \\
\hline \multirow{2}{*}{$\begin{array}{l}\text { Access to the police } \\
\text { databases }\end{array}$} & 2017 & 40 & 40 & 20 \\
\hline & 2007 & 15 & 30 & 55 \\
\hline \multirow{2}{*}{ Furniture } & 2017 & 22 & 53 & 25 \\
\hline & 2007 & 18 & 51 & 31 \\
\hline \multirow{2}{*}{ Transport/cars } & 2017 & 15 & 39 & 46 \\
\hline & 2007 & 14 & 39 & 47 \\
\hline \multirow{2}{*}{ Fuel } & 2017 & 15 & 48 & 37 \\
\hline & 2007 & 12 & 29 & 59 \\
\hline
\end{tabular}

Answers to the questions of the present survey on how the officers are provided with different kinds of tools and facilities shows a number of problems. Only with respect to the workplaces, the most common response was "fully provided" (42\%); the option "partially provided" was the most common for other supplies such as means of communication; computers; Internet access;

7 The 2007 survey covered the whole country and had a sample of 3000 officers. Ukraine, for the purposes of the study, was divided into 7 regions, Kharkiv Oblast being chosen as a typical for the northern region (Kharkiv, Sumy and Chernihiv Oblasts) and was represented by 355 officers (according to the percentage of the officers from the region in the militsiya). 
furniture; fuel for cars; access to the police databases. For the latter, however, the difference between the options "sufficiently provided" and "partially provided" was negligible. It should be noted that despite the usual "partly provided," on average $36 \%$ said to have no means of communication, computer or internet access. For the transport and stationery, the most common response was that they are 'not provided'. It could also happen that there were cars, but no fuel or fuel without cars (9 respondents).

Compared to the results of the 2007 study, there seems to be general improvement, however very modest. Two notable exceptions are, on one hand, the worsening of the perception of the supplies of workplaces and means of communication, and, on the other hand, significant improvement of the availability of Internet access and access to the police databases, which can be attributed more to the general technological development.

\section{b. The police viewed as an organisation}

In table 10 we present what the respondents thought of their organisation as a 'fair employer', a proposition which the majority of $60 \%$ denied. However, their assessments of other aspects of the police as an organization tend to be more positive.

Two questions addressed the assessment of the police efficiency by the officers themselves, concerning police as a whole and the particular branch of the police, to which they belong. Answering the first question, the majority of the respondents thought that the police is in general efficient or "rather efficient" (13 and 40\%). However, respondents tend to assess their own branch of service as more effective than the police in general (30 and 47\%). The respondents of the Parole Police displayed the most enthusiasm for the police in general (11\% efficient and 56\% "rather efficient") as well as their own branch (26 and 58\%).

Two questions concerned the assessment of the police on the scales of "order-chaos" and "reason-absurdity". While, in both cases, the majority of the respondents characterised the police as "orderly" or "more orderly than not" (15 and 52\%) and as reasonable or "more reasonable than not" (19 and 52\%), $26 \%$ of the respondents thought there was "more chaos than order" in the police work and $24 \%$ that there was more absurdity than reason. Of the respondents who thought their service to be inefficient, $45 \%$ thought "more chaos than order" is an adequate description of the police system. Unsurprisingly, those 
who found more chaos in the police system (110) also perceived more absurdity in their work (62\%).

Of the services the pre-trial investigation respondents were most critical on the 'order-chaos' variable ( $45 \%$ more chaos) as well as on the 'reason-absurdity' variable ( $40 \%$ more absurd), with more than $10 \%$ above the average for both variables ( $32 \%$ and $28 \%)$.

The other aspect of the police organisation addressed in the questionnaire was the perceived influence of the respondents' service on their personal selffulfilment. The majority of the respondents stated that their job was either fully or somewhat beneficial to their self-fulfilment (12\% and 60\%).

Another facet of the relations between the police officers and the organization is their readiness to quit the police completely or to change their branch of service. While respondents mentioned significant problems with their jobs, only a small percentage of them expressed a readiness to transfer to another police division or to quit the police entirely. $40 \%$ stated they are not going to leave the police, another $41 \%$ indicated that they do not have any specific plans to leave. Only 5\% stated they are going to leave in a period of a year, $9 \%$ plan to leave in $2-3$ years, $4 \%$ - no earlier than in 4 years. It should be noted, however, that it was the patrol police that showed the biggest readiness to leave the police: $9 \%$ stated readiness to leave in 1 year, $10 \%$ in $2-3$ years.

\section{Conclusion and discussion}

In the introduction we discussed two of the reforms and changes the police in Ukraine had to undergo in the past decades. It appeared that the design and implementation of these measures proved to be little consistent.

The first reform was aimed at abolishing the DAI, the then traffic police, widely perceived as a corrupt division. However, it continued to exist: policymakers backtracked on their plans, declaring that the goals they set had been accomplished - that was a counterfactual statement. The second reform changed the rules of the criminal procedure under which a large section of the police officers operate. While it was implemented more or less consistently, the crucial legislation necessary to support it had not been enacted yet. As we mentioned, these were the two most obvious examples of the numerous changes and reforms that affected Ukrainian police since the country declared independence in 1991. Thus, the current reform that has been initiated in the 362 
wake of Maidan Revolt might be seen as 'just another one' in a series of halfbaked policies: achieving little but burdening police officers in their day-today task fulfilment.

Despite this (justified) expectation, the current reform actually differed from the previous ones, most importantly in its scope. It established the National Police in place of the old militsiy $a$ and formulated progressive principles of policing. Most importantly, it placed much more emphasis on service- and citizen-oriented policing and the related importance of the public trust. This led to a new system of police performance assessment based on this public trust. Unfortunately, the implementation of this new assessment was delayed keeping it in the state of 'paper reform'. Currently this new assessment system is still under production and may be ready by 2020 . In addition, there was the establishment of the Patrol Police, largely staffed with newly recruited police officers.

The reverse side of the perception by the public of the police reform is that of the police officers: The present study sought to elucidate how police officers view the reform and the conditions under which they perform their duties. Obviously, a lot depends on the level of understanding of the reform, which $64 \%$ of the respondents self-assessed as complete or as partial. However, irrespective of this self-assessed knowledge almost $40 \%$ of the respondents observed no change in their work despite the reform. Singling out the two target variables of 'cooperation with the public' and 'cooperation with public agencies', we see that on these variables on average $48,5 \%$ of the respondents see no change either. When we look at the Patrol Police respondents, they perceive a positive change more often, including perceived improvements with regard to cooperation with other police forces. Unsurprisingly, Patrol Officers, more than the other respondents, thought the reform went in the right direction (44\% against $31 \%$ of the whole sample), given that the very existence of their agency was a core part of the reform.

Closely related to the perception of the reform were questions designed to estimate the officers' sensitivity for their interaction with the public. These questions concerned acceptance of the public trust as an indicator of the police efficiency, avoiding citizens' complaints and the need for a positive feedback. Additionally, this set of questions was closely related to the perception by the police officers of the improvement in cooperation with the public $(48 \%$ of the respondents saw no changes). 
Does this also apply to work conditions, from salary to legal and social protection as perceived by the respondents? A common point of these conditions is the perceived fairness of the police organisation as a responsible employer taking care of its personnel.

In general, the respondents were rather critical of the degree of fairness of their employer: the general fairness rating of the police organisation appeared to be low. Only $40 \%$ considered the police organisation fair ("completely fair" $10 \%$ and "a bit fair" $30 \%$ ) to its personnel. This is reflected in the perceptions of the salaries, protection of social and legal rights as well as the care for officers' families and proper care in cases of illness. This concerns particularly the protection in cases of legal procedures with citizens and protection against the own police organisation concerning labour and social aspects. Whether in general or in a court of law, more than $70 \%$ of the respondents felt that the common citizens are better protected than the police officers. This is a feeling of uncertainty that may affect the professional risk taking in conflict situations. The feeling of rights violation by the employer causes even more uncertainty. More than $70 \%$ thought that such was the case. Unsurprisingly, the majority of them also consider their employer to be unfair. This negative perception of rights infringements was underscored by $60 \%$ of the respondents who did not think the police organisation to be a fair employer. This points at a deep-seated lack of trust in the employer, i.e. the state in general and the police as a whole in particular, which was shared by all branches, but with the highest percentage (77\%) among respondents from the ranks of the Patrol Police, the flagship of the police reform. The situation is aggravated by the perceived insufficiency of the supplies the officers needed in order to perform their duties. This is a problem the reform still has to address.

This contrasts, however, with the apparent commitment the officers seem to feel towards their job. $72 \%$ of the police officers expressed the opinion that their job fully or somewhat contributes to their self-fulfilment. $53 \%$ of the officers assessed the work of the police as a whole efficient or "rather efficient". Assessing their own department, they were even more generous: 77\% thought it was efficient or rather efficient. Moreover, despite being dissatisfied with the conditions of their work, the respondents did not show much inclination to leave the police. Only $18 \%$ of the respondents expressed a willingness to quit their jobs. It should be noted, however, that it was the officers from the Patrol Police who were the most eager to quit. This corresponds with the 
greater willingness of the young officers (duration of service less than 3 years and 3 to 5 years) to quit.

To what should we attribute this attitude? There is no unambiguous answer: younger staff may more optimistically perceive job opportunities even in a halting labour market, while older staff may be more pessimistic and prefer a 'fixed job'. In addition, there may be a loyalty to their service where they worked for many years.

These observations lead to two conclusions. In the first place, a significant part of respondents claim to understand the importance of the public opinion for their work. Still, a large part of the officers show ambivalence towards the reform, stating that it is difficult for them to assess their understanding of the reform, to determine whether it moves into the right direction or whether the public trust is an adequate reflection of their work.

A nation-wide survey is required in order to gain a fuller picture across the country; however, it seems that there remains a lot to do in order to instil in the officers a willingness to actively implement provisions of the reform in their day-to-day job.

This relates to our second conclusion. To maintain this positive momentum the police organisation should invest more effort in its relationship with its employees: the driver must instil trust in his horses that pull the reform cart. It is naïve to expect the police officers to accept the police reform enthusiastically if it does not also improve their working and living conditions. The other, more general aspect of this is the trust of the police officers in their organisation they are working for, i.e. the police and the state more generally, to ensure their legal and social protection. If it is the aim that the public trust is the reflection of the quality of the police work, the trust of the police officers must be a reflection of the quality of the National Police as a fair employer.

\section{References}

Maltsev, V. V., Hromadska dumka u systemi otsinky diialnosti orhaniv vnutrishnikh sprav Ukrainy [Public Opinion in the System of Performance Evaluation of the Bodies of Internal Affairs of Ukraine] (Candidate of Sciences Dissertation), 2005. 
Markovska, A. and A. Serduyk, Dysfunctional social institutions as an obstacle to tackle crime: exploring the dilemma of a good Ukrainian policeman. In: P.C. van Duyne, J. Harvey, G.A. Antonopoulos, K. von Lampe, A. Maljevic, Jon Spencer (eds.). Human dimensions in organised crime, money laundering and corruption. Nijmegen: Wolf Legal Publishers, 2013.

Martynenko, O.A., Kryminolohichna kharakterystyka pravopo rushen, shcho vchyniuiutsia pratsivnykamy OVS Ukrainy [Criminological Characteristics of the Offences Perpetrated by the Employees of the Bodies of Interior]. Pravo i bezpeka [Law and Security] 2004, 3(2), 78-82.

Serdyuk O. O., Publichna bezpeka ta dovira do pravookhoronnykh orhaniv. Za rezul'tatamy doslidzhen' 2013-2018 rokiv, provedenykh $v$ Kharkivs 'kii oblasti [Public security and confidence in the law enforcement agencies. Based on the results of the studies of 2013-2018, conducted in Kharkiv Oblast] : naukovyi zvit [report]. Kharkiv, 2018.

Stan zakhyshchenosti prav, osnovnykh svobod i sotsial'nykh harantii pratsivnykiv OVS Ukrainy [State of protection of the rights, basic liberties and social guarantees in the agencies of interior of Ukraine] : monograph / Yu.L. Bielousov, D.O. Kobzin, Yu.O. Sviezhentseva et al.; ed. by K.B. Levchenko. Kyiv, 2008.

Zozulia I.V., Derzhavna avtoinspektsiia yak obiekt reformuvannia v systemi MVS Ukrainy [State Automobile Inspection as an Object of Reform in the System of MIA of Ukraine]. Forum prava [Forum of Law], 1, 164-186. 